\title{
Process and Environmental Benefit of Recycling of Waste Papers
}

\author{
Vijay Kumar, J. S. Kalra, Devvret Verma, Shipra Gupta
}

\begin{abstract}
Paper is a fundamental part of most aspects of society; worldwide a total of approximately three hundred million tons of paper are produced each day and approximately $90 \%$ of this paper is produced from mature pulp wood. In addition, the demand of paper is expected to increase. Today the finest of paper are produced all over the world. But one dismaying fact is that millions of trees are fell in a day to make paper. Increase demands of paper production and limited wood resources have directed researchers to look for appropriate additional resources of non-wood material (waste papers) for pulp and paper manufacturing. Setting up of handmade paper unit has the capability of recycling waste paper and cotton rags into fine quality handmade paper. Not only does this initiative conserve environmental resources but also helps in providing employment to pupil from the unskilled and marginalized strata of society.
\end{abstract}

Key Words: Recycling, waste papers, Environmental benefit, Pollution control

\section{INTRODUCTION}

Paper recycling helps to reduce the intensity of use of natural resources, decreases the need of waste disposal, decreases the specific energy consumption in paper manufacturing and, usually, also provides reasonable levels of profits for those in the business. The saving in terms of uncut trees and energy consumption, provided by the recycle papers vary according to the raw material quality and technologies employed. In average terms, however, it can be stated thirty $\mathrm{kg}$ of waste paper avoids the falling of a eucalyptus tree and twenty $\mathrm{kg}$ of recycle paper a pine tree. As per U. S. E. P. Agency, 34\% water pollution and $74 \%$ air pollution become less in recycling process than new paper production. New paper mills are responsible for both air and water pollution. Handmade paper will decrease the demand of new papers and also reduces the pollution in environment.

\section{IMPORTANCE OF RECYCLING}

The pollution which is produced due to production of paper by paper mills is called paper pollution. In municipal solid waste of a city, $35 \%$ garbage are available in the form of waste papers [1].Recycling of papers may be a source of pollution if de-inking process is done by the use of chemicals [2].

Revised Manuscript Received on September 25, 2019.

Vijay Kumar, Professor, Department of Physics, Graphic Era Hill University, Dehradun, Uttrakhand, India.

J. S. Kalra, A P, Department of Mechanical Engineering, Graphic Era Hill University, Dehradun, Uttrakhand, India

Devvret Verma, A. P. Department of Biotechnology, Graphic Era Deemed to be University, Dehradun, Uttrakhand, India.

Shipra Gupta, Associate Professor, Department of Commerce, Graphic Era Hill University, Dehradun, Uttrakhand, India. Email:drshipragupta16@gmail.com
As per Canadian Citizen's Association, the people and government require paper and paper products with sustainable environmentally safe environment[3]. The requirement of paper and their products are very huge in amount, so the environmental impact is also very important. According to one study,paper mills have the manufacturing order of 500 million tons of paper and paperboard by 2020[4]. So excessive ways are required which confirm that the production of paper is a pollution controlled activity.

Paper factories are the third biggest ventures which are answerable for air and water contamination around the world. Every year these enterprises are released about one hundred million kilogram of toxic sullying [5]. The paper mills are the $5^{\text {th }}$ greatest customer of imperativeness, speaking to $4 \%$ of entire world's essentialness employ. Additional water is used by crush and paper industry to make an immense measure of thing than some other industry [6]. The use of paper is increased by four hundred percent from the past 40 years and thirty five percent of accumulated trees for new pulp making. The greater part of wood for paper making is found by domain forest, is usually a monoculture and this raise stresses over the organic special effects of the preparation. More than 65 lacs trees were cleaved behind to manufacture 16 billion cups of paper. In 2006, those were used by US purchasers for coffee. For this 4 billion US gallons of water and by waste achieving 253 million pounds. Generally speaking, $58 \%$ cups of papers are utilised by North Americans[10]. If we recycle $40 \mathrm{~kg}$ of waste papers, we can save one green tree of the forest. Thus the person or Institute who recycle the waste papers, is contribute to the environment conservation indirectly [7].

\section{POLLUTION}

During the process of manufacturing of new papers, $\mathrm{NO}_{2}$, $\mathrm{SO}_{2}$ and $\mathrm{CO}_{2}$ are emitted and spread in atmosphere. $\mathrm{NO}_{2}$ and $\mathrm{SO}_{2}$ are significant benefactors of corrosive downpour, while $\mathrm{CO}_{2}$ is an ozone depleting substance liable for environmental change. Wastewater releases for a mash and paper factory contains solids, supplements and broke up natural issue. The leftover of these synthetics are hurtful for the human wellbeing $[8,9]$.

\section{RECYCLING OF WASTE PAPERS}

One stress over reusing wood pound paper is that the strands are tainted with each and in the wake of being reused four or on different occasions the fibres turn into unnecessarily small and weedy to be helpful in making paper [11, 12]. Reusing of waste papers is one of the less tangled frameworks in the reusing industry.

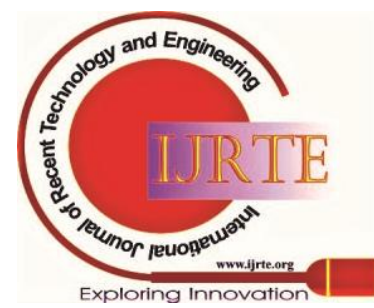


Most reused paper is evaluated higher than recently prepared paper, and as per this act to plays an indispensable feature for the client. Since by far mainly reused squash is purchased in an open market, fresh paper has conveyed more affordable by the crush which was prepared by the specific paper processing plant. No reused content contains in new paper. This is ready truly by the squash of trees or cotton. Materials recovered after the creating process of basic paper are considered reused paper. Since that one of a kind pattern was so muddled, some "reused papers" enclosed just processing plant leftovers that would have been associated with new paper at any rate [13]. Measures have starting late been place to shield associations from making it look like they were trade reused paper. The arrangements as well as reusing ventures have concentrated on the bits of paper that is disposed of by consumers step by step in order to construct the proportion of reused paper. Unmistakable paper plants are composed for various kinds of paper, and mostly "recovered office paper can be sent to a deinking mill". The creation method for reused paper is more costly than the particularly made paper forms with the use of trees. The technique of making reused paper is moreover extensively progressively dreary. In any case, reusing paper has an enormous number of focal points from a biological perspective $[14,15]$.

\section{A. Process of making of handmade in paper plant without use of any chemical}

The following process is used to make handmade paper from the recycling of waste papers.

i. Beater: Beater is used to make the pulp of waste papers and rags, beater is used. Size of beater depends upon how much waste papers you want to convert into pulp. Many researchers are recommended some chemicals like synthetic adhesive, guar gum, resin etc. But we can make handmade papers without any use of chemicals. The appropriate percentage of rags with waste papers makes the paper strong without any use of chemicals. This type of papers become perfectly eco-friendly.

ii. Auto vat: This part is used to filter and uniform distribution of the pulp of waste paper.

iii. Screw press machine: In this press, the uniform distributed pulp is pressed by a load. The uniformly distributed pulp is spread on cotton cloth. This press machine helps to decrease the moisture in pulp. The pulp on cotton cloth can be dried in Sunlight.

iv. Rolling machine: the fourth part of this plant is rolling machine. After dry of the pulp, the handmade paper becomes ready. This dry handmade paper is passed through the roller of rolling machine. After passing through the roller, the handmade paper becomes smooth and fine.

v. Cutting machine: The last part of the plant of handmade paper is cutting machine. The sides of ready papers are very rough and no uniform. By the help of cutting machine, the sides of papers become fine and sharp.

Now the paper becomes ready to prepare product of handmade paper.

\section{B. Types of products}

i. Thin handmade paper: If thickness of handmade papers are very thin, it can be used to make diary, note books etc. After deinking and cutting in A4 size, the papers can be used to take print out from laser printer and can also use in Photostat machine.

ii. Thick handmade paper: This type of paper are used to make cover of books, note books, in packing of costly material etc. After folding and making arrangement of documents connector, the thick paper can also use to make file cover for office purposes. The life of these file cover is more than the cover made by virgin papers.

iii. Soft thick handmade paper: If thickness of handmade is very thick, it used as thumb pin notice boards which are used to paste general notice. This type of notice boards are used in schools, colleges, University campus and offices etc. Soft thick papers can also use in packing of electronic items to protect from the jerk during transportation. Soft thick papers can also use to absorb sound wave to reduce eco in auditorium.

iv. Hard thick handmade paper: This types of papers are used as hard board. Hard boards are used as writing pad etc.

v. Any shape idol: After mixing some adhesive like gwargum, resin etc. with the waste papers pulp, the pulp can convert into any shape. We can make idol of different shapes, packing materialslikeeggtray, papertray which are used in transformer as an insulator etc.

\section{CONCLUSION}

After above discussion, it is concluded that to protect green forest, the use of the new papers which are making by wood pulps should be decreased. It can also protect our environment. New papers mills are responsible for water pollution, land pollution and air pollution. Recycling of waste papers are the solution of these problems. As we can recycle a paper seven times, thus we should recycle the waste papers and should make handmade papers or products. The handmade papers are eco-friendly and no harmful chemicals are used to make handmade paper.

\section{SUGGESTIONS}

i. In general the waste papers of offices and packing materials which are obtained from lab equipment are destroyed by the Colleges and the Universities. If a small unit is installed in each school, college and university campus, the demand of new paper will decrease abruptly which is very helpful for the life of forest.

ii. The training program should be organised at school and college level so that students become inspire and cooperate for making of handmade papers.

iii. Government of each country should encourage the people for recycling of waste papers. Research fund should be released by the research agencies so that

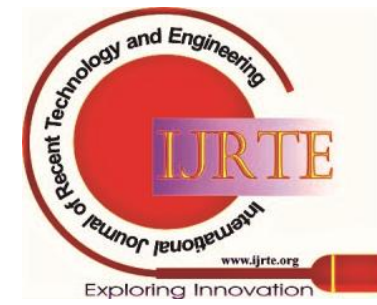




\section{REFERENCES}

1. Effluents from Pulp Mills using Bleaching - PSL1. Ottawa, ON: Health Canada and Environment Canada. 1991. ISBN 0-662-18734-2. Retrieved 2010-07-26.Catalog no. En40-215/2E.

2. Tarkpea, Maria; et al. (1999). "toxicity of conventional, elemental chlorine-free, and totally chlorine-free kraft-pulp bleaching effluents assessed by shortterm lethal and sublethal bioassays". Environmental Toxicology and Chemistry 18 (11): 2487-2496. doi:10.1002/etc.5620181115.

3. Sonnenfeld, David A. (1999). "Social Movements and Ecological Modernization: The Transformation of Pulp and Paper Manufacturing, Paper: WP00-6-Sonnenfeld". Berkeley Workshop on Environmental Politics. Berkeley, CA: Institute of International Studies (University of California, Berkeley). Retrieved 2007-09-20.

4. Auer, Matthew R. (1996). "Negotiating toxic risks: A case from the Nordic countries," Environmental Politics 5: 687-699.

5. Bennis, H., Benslimane, R., Vicini, S., Mairani, A. \&Princi, E. (2010). Fibre width measurement and quantification of filler size distribution in paper-based materials byS EM and image analysis. Journal of Electron Microscopy 59 (2), 2010, pp.91-102.

6. Khantayanuwong, S. (2003). Determination of the Effect of Recycling Treatment on Pulp Fiber Properties by Principal Component Analysis. Kasetsart J. (Nat. Sci.) 37, pp. 219 - 223.

7. Kučerová, V. \& Halajová, L. (2009). Evaluation of changes of the recycled pulps by method thegelpermeationchromatography.ActaFacultatisXylologiaeZvolen,51 (2),2009, pp. 87-92.

8. Malesic,J.,Kolar,J.,Strlic,M.,Kocar,D.,Fromageot,D.,Lemaire,J.\&Hail lant,O.(2005). Photo-induced degradation of cellulose. Polymer Degradation and Stability89(1),pp. 64-69.

9. Nazhad, M. M. (2005). Recycled fibre quality - A review', Journal of industrial and engineeringchemistry, In: Korean Journal,11(3),314

10. Pati, R.K., Vrat, P. \& Kumar, P. (2008). A goal programming model for paper recycling system. Omega 36, 2008, pp. $405-417$

11. Song, X. \& Law, K.N. (2010). Kraft pulp oxidation and its influence of recycling characteristics of fibres. Cellulose Chemistry and Technology 44 (7-8),pp.265-270.

12. Zanuttini, M. A., McDonough, T. J., Courchene, C. E. \& Mocchiutti, P. (2007). Upgrading OCC and recycled liner pulps by mediumconsistency ozone treatment. Tappi Journal 6(2), pp. 3-8.

13. Zervos,S.\&Moropoulov,A.(2005).Cottoncelluloseageinginsealedvesse 1s. Kineticmodel ofautocatalyticdepolymerization.Cellulose12,2005,pp.485-496.

14. Čabalová, I., Kačík, F. \&Sivák, J. (2009). Changes of molecular weight distribution celluloseduringpulprecycling.ActaFacultatisXylologiaeZvolen51(1),2 009,pp.11- 17, ISSN1336-3824

15. Čabalová,I.,Kačík,F.\&Sivák,J.(2011).Thechangesofpolymerizationde greeofsoftwood fibers by recycling and ageing process. Acta Facult at is Xylologiae Zvolen53 (1), 2011, pp. 61-64, ISSN1336-3824. 